\title{
ZAKRES OCHRONY PODATNIKÓW UNIKAJĄCYCH OPODATKOWANIA W KONTEKŚCIE ZASADY IN DUBIO PRO TRIBUTARIO I ZASAD SYSTEMOWYCH CIT
}

Streszczenie. W ramach niniejszej publikacji zostają przedstawione kluczowe zagadnienia związane z problematyką ochrony podatników unikających opodatkowania. Problem ten jest analizowany zwłaszcza w kontekście zasady in dubio pro tributario, zasad systemowych CIT oraz klauzuli ogólnej obejścia prawa podatkowego. Pod adresem ustawodawcy zostają sformułowane postulaty de lege lata oraz de lege ferenda dotyczące skonstruowania odpowiedniej korelacji (współzależności) między tymi zagadnieniami.

Słowa kluczowe: unikanie opodatkowania, zasada in dubio pro tributario, wewnątrzkrajowe środki antyabuzywne, klauzula ogólna obejścia prawa podatkowego, zasada powszechności opodatkowania.

1. WSTĘP

Na przestrzeni ostatnich lat ustawodawca podejmuje coraz intensywniejsze działania skierowane przeciwko zjawisko unikania opodatkowania w podatku dochodowym od osób prawnych [CIT]. Uchwalane są kolejne pakiety mające uszczelnić pobór CIT poprzez likwidację sztucznych struktur podatkowych odpowiedzialnych za funkcjonowanie unikania opodatkowania. Działania ustawodawcy nie skupiają się praktycznie w żadnym stopniu na zidentyfikowaniu strukturalnych przyczyn występowania

* Doktor nauk prawnych, doradca podatkowy i ekspert ds. prawnych różnych instytucji państwowych oraz organizacji przedsiębiorców, e-mail: j.jankowski@onet.eu 
unikania opodatkowania, co tylko potęguje narastanie zjawiska inflacji prawa podatkowego. W wyniku wprowadzanych zmian, CIT w coraz mniejszym stopniu przypomina klasyczny podatek dochodowy i ewoluuje w kierunku bliżej nieznanym. Można już wręcz mówić o kryzysie konstrukcji podatku dochodowego od osób prawnych w obecnej wersji. W ramach niniejszej publikacji przeanalizowana zostaje problematyka ochrony podatników unikających opodatkowania w kontekście zasady in dubio pro tributario i zasad systemowych CIT. Skonstruowanie odpowiedniej korelacji (współzależności) między tymi zagadnieniami na poziomie ustawowym może być bowiem znacznie efektywniejszym narzędziem przeciwdziałania unikaniu opodatkowania niż obszerne pakiety uszczelniające.

\section{PRZESŁANKI FUNKCJONOWANIA „LEGALNEGO” UNIKANIA OPODATKOWANIA W CIT}

W doktrynie prawa podatkowego wskazuje się, że możliwość funkcjonowania „legalnego" unikania opodatkowania ${ }^{1}$ w CIT jest spowodowana istnieniem trzech zasadniczych dylematów dotyczących wykładni prawa podatkowego:

1. Czy prawo podatkowe powinno być interpretowane ściśle, bez możliwości stosowania wykładni rozszerzającej poprzez odwołanie się do wykładni celowościowej lub analogii?

2. Czy prawo podatkowe powinno być przedmiotem „wykładni ekonomicznej"?

3. Czy prawna forma transakcji powinna być uwzględniana przed jej treścią? ${ }^{2}$

Przesłanki te, pomimo że zostały sformułowane na początku XXI wieku, nadal zachowują aktualność i - po nieznacznych modyfikacjach - mogą zostać wykorzystane do weryfikacji pytania, czy na gruncie obecnie

${ }^{1}$ Dla celów niniejszej publikacji przez unikanie opodatkowania rozumie się działanie podatnika ukierunkowane wyłącznie na osiągnięcie korzyści podatkowej i jednocześnie pozbawione uzasadnienia ekonomicznego. Taki też pogląd prezentowany jest w najnowszej literaturze przedmiotu - J. Jankowski, Optymalizacja podatkowa w podatkach dochodowych - dopuszczalność oraz prawne granice, Warszawa 2019, s. 45; M. Kondej, Granice optymalizacji podatkowej w podatkach dochodowych przed wejściem w życie klauzuli przeciwko unikaniu opodatkowania, Poznań 2017, s. 181-182.

${ }^{2}$ M. Kalinowski, Granice legalności unikania opodatkowania w polskim systemie podatkowym, Toruń 2001, s. 73. 
istniejącego stanu prawnego spełnione są warunki umożliwiające „legalne” unikanie opodatkowania? Niemniej przed wykorzystaniem tych przesłanek do zbadania opisanego problemu, zasadne jest poczynienie pewnych uwag o charakterze „technicznym”.

Po pierwsze, powstaje pytanie, czy ww. przesłanki (zasady wykładni prawa podatkowego) znajdują zastosowanie zawsze, bez jakichkolwiek wyjątków? Czy stwierdzenie zaistnienia sytuacji unikania opodatkowania uprawnia administrację skarbową lub sądy administracyjne do zmiany zasad wykładni ad casum? Kwestia ta ma istotne znaczenie, ponieważ przykładowo wykładnia ekonomiczna może funkcjonować jako dyrektywa wykładni drugiego stopnia (dyrektywa wyboru) albo doktryna orzecznicza skierowana przeciwko unikaniu opodatkowania. W związku z powyższym, dalszej analizie zostanie poddana również kwestia zakresu ochrony podatników unikających opodatkowania na tle pozostałych podatników w kontekście obowiązujących zasad wykładni.

Po drugie, w polskim systemie podatkowym obowiązują gwarancje proceduralno-instytucjonalne chroniące podatników przed arbitralnością administracji skarbowej w interpretacji treści przepisów ustaw podatkowych.

W konsekwencji należy rozważyć, czy również w tym zakresie ochrona podatników unikających opodatkowania jest taka sama jak w przypadku pozostałych podatników.

\section{Podstawowe Zasady WykŁadni praWa podatkowego w CIT}

(ZAGADNIENIA WĘZŁOWE)

Ze względu na ingerencyjny i tetyczny charakter prawa podatkowego wskazuje się, że pierwszeństwo w procesie ustalania wykładni przepisów podatkowych należy przyznać wykładni językowej ${ }^{3}$. Oczywiście, zasada pierwszeństwa wykładni językowej nie ma charakteru absolutnego i należy raczej traktować ją jako punkt wyjścia przy interpretacji przepisów podatkowych. Można bowiem spotkać się z poglądami, iż językowy sens przepisu powinien być skonfrontowany $\mathrm{z}$ innymi przepisami oraz uwzględniać cel regulacji prawnej ${ }^{4}$. Nie jest to jednak możliwe w przypadku, gdy odejście od literalnego brzmienia przepisu prowadziłoby do zwiększenia podstawy opodatkowania w oparciu o kryteria pozaustawowe. Wówczas taka

\footnotetext{
${ }^{3}$ Uchwała NSA z 17 stycznia 2011 r., sygn. akt II FPS 2/10.

${ }^{4}$ Wyrok NSA z 21 lutego 2018 r., sygn. akt II FSK 176/15.
} 
interpretacja przepisów jest uznawana za wykładnię contra legem ${ }^{5}$. Administracja skarbowa nie może korygować jednoznacznego brzmienia przepisu ustawy podatkowej w sposób niekorzystny dla podatników w drodze pozajęzykowych metod wykładni, a zwłaszcza wykładni celowościowej ${ }^{6}$.

W prawie podatkowym obowiązuje bowiem nakaz wykładni ścisłej, a w szczególności zakaz stosowania takiej wykładni rozszerzającej przepisów prawa podatkowego, która zwiększałaby zakres obciążeń podatkowych podatnika. Wykładnia rozszerzająca jest dopuszczalna jedynie na korzyść podatnika ${ }^{7}$. Fundamentalną zasadą prawa podatkowego jest to, że zakres przedmiotu opodatkowania musi być precyzyjnie określony w ustawie podatkowej, a interpretacja jej przepisów nie może być rozszerzająca ${ }^{8}$. Niniejsza dyrektywa wykładni wynika bezpośrednio z przepisów Konstytucji RP, a w szczególności z art. 217, zgodnie z którym „nakładanie podatków, innych danin publicznych, określanie podmiotów, przedmiotów opodatkowania i stawek podatkowych, a także zasad przyznawania ulg i umorzeń oraz kategorii podmiotów zwolnionych od podatków następuje w drodze ustawy” (art. 217 Konstytucji RP). W myśl natomiast art. 84 Konstytucji „Każdy jest obowiązany do ponoszenia ciężarów i świadczeń publicznych, w tym podatków, określonych w ustawie”. Przepisy te interpretowane łącznie wprowadzają konstytucyjną zasadę ustawowego nakładania podatków (zasada nullum tributum sine lege) ${ }^{9}$. Zasada ta zakazuje tworzenia pozaustawowych podatkowoprawnych stanów faktycznych poprzez stosowanie analogii czy wykładni rozszerzającej.

Stosowanie analogii jest możliwe - na zasadzie wyjątku - tylko wówczas, gdy wypełnienie istniejącej luki legislacyjnej jest korzystne dla podatnika, a więc wtedy, gdy nie nastąpi rozszerzenie zakresu jego obowiązków

${ }^{5}$ Wyrok NSA z 28 października 2015 r., sygn. akt II FSK 3048/13; A. Mariański, Rozstrzyganie wątpliwości na korzyść podatnika, cz. II, „Przegląd Podatkowy” 2009, nr 10, s. 39.

${ }^{6}$ Wyrok NSA z 17 lutego 2016 r., sygn. akt II FSK 3585/13.

${ }^{7}$ Por. L. Morawski, Wykładnia w orzecznictwie sądów, Toruń 2002, s. 266.

${ }^{8}$ Wyrok WSA w Bydgoszczy z 12 listopada 2013 r., sygn. akt I SA/Bd 793/13.

${ }_{9}$ Zdaniem M. Kalinowskiego, przepis art. 217 Konstytucji jedynie uzupełnia art. 84, regulując wymagania co do treści ustawy, która ma nałożyć na obywatela obowiązek ponoszenia świadczenia podatkowego (por. M. Kalinowski, op. cit., s. 57). Wniosek ten może wydawać się niezasadny wobec umieszczenia art. 84 Konstytucji w rozdziale II o tytule „Obowiązki”, jednakże w treści przepisu art. 84 Konstytucji - zgodnie z zasadami składni języka polskiego - nacisk jest położony na zwrot „określony w ustawie”, tzn. obowiązek zapłaty podatku wynikać musi z ustawy (B. Brzeziński, Wstęp do nauki prawa podatkowego, Toruń 2003, s. 140-141). 
daninowych. W prawie podatkowym, w przeciwieństwie do prawa prywatnego, sięganie do analogii z ustawy (analogia legis), a nawet analogii z prawa (analogia iuris), polegającej na sformułowaniu nowej normy, wypełniającej stan luki prawnej i jednocześnie kreującej nowy prawnopodatkowy stan faktyczny, w oparciu o pewne ogólne wartości (np. zasady prawa, domniemane preferencje aksjologiczne ustawodawcy), nie jest dopuszczalne ${ }^{10}$. Podatnik nie może ponosić konsekwencji ewidentnych błędów i zaniedbań prawodawcy, w tym zwłaszcza takich, które powodują lukę w prawie naruszającą podstawowe zasady porządku konstytucyjne$\mathrm{go}^{11}$. Analogia w prawie podatkowym może co najwyżej uzupełniać luki konstrukcyjne (techniczne, rzeczywiste) uniemożliwiające właściwe stosowanie prawa podatkowego ${ }^{12}$.

Judykatura oraz doktryna dotychczas nie wykształciły jednolitego rozumienia wykładni gospodarczej (ekonomicznej). Zdaniem B. Brzezińskiego, wykładnia gospodarcza oznacza stosowanie przepisów prawa w kontekście założenia, że podatnik działa i powinien działać w sposób typowy dla podmiotów prowadzących działalność gospodarczą ${ }^{13}$. Wykładnia gospodarcza według tej koncepcji opiera się na dwóch podstawowych założeniach:

1. Podatnik powinien zachowywać się z jednej strony gospodarczo racjonalnie, $\mathrm{z}$ drugiej zaś - podatkowo neutralnie.

2. Wszyscy podatnicy powinni podlegać adekwatnemu obciążeniu podatkowemu, tj. płacić podatek w wysokości odpowiadającej ogólnym założeniom konstrukcji podatku, z uwzględnieniem przysługujących ulg i zwolnieńn ${ }^{14}$.

R. Mastalski zalicza wykładnię gospodarczą do wykładni celowościowej. Zmierza ona $\mathrm{w}$ tym wypadku do interpretacji tego prawa $\mathrm{z}$ punktu widzenia gospodarczej rzeczywistości, wyraźnie rozróżniając treść oraz cywilnoprawną formę czynności prawnych ${ }^{15}$. Nacisk położony jest na prawdziwą treść tych czynności, a nie ich zewnętrzną formę (ekonomiczna analiza opodatkowania).

Wykładnia gospodarcza odpowiadająca koncepcji B. Brzezińskiego i R. Mastalskiego to tak naprawdę dyrektywa wykładni I stopnia, zakładająca opodatkowanie czynności prawnych według kryteriów ekonomicznych

\footnotetext{
${ }^{10}$ Wyrok NSA z 5 kwietnia 2016 r., sygn. akt II FSK 462/14.

${ }^{11}$ Wyrok NSA z dnia 24 października 2006 r., sygn. akt I FSK 93/06.

${ }^{12}$ Wyrok NSA z dnia 29 sierpnia 2012 r., sygn. akt II FSK 166/11.

${ }^{13}$ B. Brzeziński, Wykładnia prawa podatkowego, Gdańsk 2013, s. 163.

${ }^{14}$ B. Brzeziński, Wykładnia prawa..., s. 164.

${ }^{15}$ R. Mastalski, Stosowanie prawa podatkowego, Warszawa 2008, s. 94.
} 
i przyznanie pierwszeństwa regule interpretacji zachowań podatnika według koncepcji „treść nad formą”. Realizacja postulatu adekwatnego opodatkowania wymagałaby istnienia konkretnej podstawy prawnej w przepisach podatkowych i mogłaby pozostawać w sprzeczności z konstytucyjną zasadą nullum tributum sine lege. Opodatkowanie czynności podatnika według zasady „treść nad formą” wiązałoby się z koniecznością przyjęcia stanowiska świadczącego o autonomii prawa podatkowego w stosunku do prawa cywilnego, zgodnie z koncepcją „pojęć swoistych” lub „wolą ustawodawcy"16.

Ekonomiczna wykładnia prawa podatkowego może być również rozumiana jako doktryna służąca zwalczaniu unikania opodatkowania. W polskim systemie podatkowym nie funkcjonują, na wzór krajów common law, doktryny orzecznicze mające zapobiegać unikaniu opodatkowania (np. doktryna substance over form czy business purpose) ${ }^{17}$. W stanie prawnym obowiązującym do 31 grudnia 2002 r., gdy w polskim systemie podatkowym nie funkcjonowała klauzula obejścia prawa podatkowego (GAAR - ang. general anti-avoidance rules) w wersji normatywnej, administracja skarbowa i sądownictwo administracyjne próbowały zwalczać unikanie opodatkowania na podstawie art. 58 k.c. oraz koncepcji autonomii prawa podatkowego. Koncepcja ta polegała na stosowaniu przepisów kodeksu cywilnego dotyczących obejścia prawa do podważenia skutków czynności prawnych podatników na gruncie prawa podatkowego. Ostatecznie „precedensowy” wyrok NSA z 24 listopada 2003 r. w sprawie Optimusa (sygn. akt FSA 3/03) spowodował upadek sądowej klauzuli obejścia prawa podatkowego ${ }^{18}$. W związku z akcesją Polski do Unii Europejskiej, w niektórych wyrokach sądów administracyjnych można zauważyć tendencję powrotu do koncepcji sądowej klauzuli obejścia prawa podatkowego $^{19}$. Klauzula ta na gruncie podatków dochodowych znajduje jednak zastosowanie w bardzo ograniczonym zakresie i nie jest w zasadzie stosowana przez sądy administracyjne do podważania skutków podatkowych

${ }^{16}$ C. Kosikowski, Autonomia prawa podatkowego - głos krytyczny, „Przegląd Podatkowy" 2006, nr 7, s. 8-9.

${ }^{17}$ Więcej na temat poszczególnych anglosaskich doktryn orzeczniczych w: B. Brzeziński, R. Korgol, Doktryna substance over form w orzecznictwie podatkowym sądów w Kanadzie, „Toruński Rocznik Podatkowy” 2011, s. 60-88.

${ }^{18}$ B. Brzeziński, Narodziny i upadek orzeczniczej doktryny obejścia prawa podatkowego, „Przegląd Orzecznictwa Podatkowego” 2004, nr 1, s. 7 i nast.

${ }^{19} \mathrm{~K}$. Radzikowski, Obejście prawa podatkowego w najnowszym orzecznictwie sądów administracyjnych, „Przegląd Podatkowy” 2010, nr 6, s. 14 i nast. 
skomplikowanych i wielopiętrowych sztucznych struktur podatkowych ${ }^{20}$. Zdarzają się przy tym pojedyncze przypadki, gdy sądy administracyjne na podstawie art. 199a Ordynacji podatkowej (dalej: O.p.) przyznają administracji skarbowej kompetencję do dokonywania, dla celów prawa podatkowego, ustalenia treści czynności cywilnoprawnej ${ }^{21}$.

Z uwagi na konstytucyjne standardy w zakresie tworzenia i stosowania prawa podatkowego oraz brak hierarchii poszczególnych dyrektyw wykładni na poziomie ustawowym, za reprezentatywne należy uznać następujące ogólne zasady wykładni prawa podatkowego:

- nakaz stosowania wykładni literalnej przepisów prawa podatkowego;

- zakaz stosowania wykładni rozszerzającej w prawie podatkowym, jeżeli wykładnia taka miałaby prowadzić do rozszerzenia zakresu należności podatkowych, a to ze względu na zasadę nullum tributum sine lege;

- zasadę, zgodnie z którą przepisy wprowadzające przywileje podatkowe mają charakter wyjątkowy i nie mogą podlegać wykładni rozszerzającej;

- regułę, w myśl której wolności i uprawnienia mogą być interpretowane rozszerzająco ${ }^{22}$.

\section{GAAR A „LEGALNOŚĆ” UNIKANIA OPODATKOWANIA}

GAAR - wprowadzona ponownie do polskiego systemu podatkowego w wersji normatywnej w roku $2016^{23}$ - nie jest wykładnią prawa podatkowego sensu stricte. Nie polega ona bowiem na „odpowiednim” stosowaniu przepisów ustawy podatkowej do faktów niemieszczących się w podatkowoprawnym stanie faktycznym na zasadzie analogii, lecz uznaniu tychże faktów - w drodze fikcji prawnej - za fakty innego rodzaju, mieszczące się $\mathrm{W}$ podatkowoprawnym stanie faktycznym ${ }^{24}$. Skutkiem zastosowania GAAR jest reklasyfikacja stanu faktycznego dla celów podatkowych

${ }^{20}$ N. Kociak, Wykładnia gospodarcza $w$ orzecznictwie sądów administracyjnych, „Przegląd Podatkowy” 2018, nr 4, s. 42 i nast.

${ }^{21}$ Tak np. wyrok WSA w Szczecinie z 4 kwietnia 2018 r., sygn. akt I SA/Sz 130/18, orzeczenie nieprawomocne.

22 Zasady usystematyzowane przez Lecha Morawskiego. Zob. L. Morawski, Wstęp do prawoznawstwa, Toruń 1999, s. 165-166.

${ }^{23} \mathrm{Na}$ mocy ustawy z 1 maja 2016 r. o zmianie ustawy - Ordynacja podatkowa oraz niektórych innych ustaw (Dz. U. z 2016 r., poz. 846); dalej: ustawa wprowadzająca GAAR.

${ }^{24}$ B. Brzeziński, Wykładnia prawa..., s. 169. 
według kryterium czynności odpowiedniej bądź uznanie stanu faktycznego za nieistniejący ${ }^{25}$.

Pomimo że GAAR nie jest instytucją związaną z wykładnią prawa podatkowego, należy uznać, że ostatni warunek funkcjonowania „legalnego” unikania opodatkowania nie jest spełniony. Administracja skarbowa dysponuje bowiem narzędziem, które pozwala na opodatkowanie czynności prawnych podatników na podstawie kryterium „treść nad formą”. Czy zatem unikanie opodatkowania jest nadal „legalne”, skoro działania takie wchodzą w zakres hipotezy GAAR? Niewłaściwe zrozumienie tego, jak GAAR wpływa na „legalność” unikania opodatkowania, może prowadzić do wyciągnięcia nazbyt uogólnionych wniosków co do faktycznej natury prawnej tego zjawiska. W konsekwencji, do posługiwania się terminem „legalność" unikania opodatkowania, w zależności od aktualnie obowiązujących zasad wykładni przepisów podatkowych w systemie podatkowym ${ }^{26}$, należy podchodzić niezwykle ostrożnie.

Ustawodawca podatkowy może „oficjalnie” nie akceptować unikania opodatkowania, lecz jednocześnie nie wprowadzać w tym zakresie żadnych zakazów czy nakazów. Wówczas można mówić o „cichej tolerancji” ustawodawcy dla funkcjonowania tego zjawiska. Działania podatników unikających opodatkowania są wtedy uznawane za „pośrednie łamanie prawa podatkowego" lub „pozornie legalne” 27 , ponieważ pomimo swego ewidentnie negatywnego wydźwięku w odbiorze społecznym, są prawnie dopuszczalne. Obowiązywanie GAAR nie wprowadza żadnych nowych standardów uznawania „legalności” unikania opodatkowania, lecz wyłącznie wyposaża administrację skarbową w efektywne narzędzie przeciwdziałania temu zjawisku ${ }^{28}$. Fakt, iż ustawodawca zaczyna podejmować działa-

${ }^{25}$ Art. 119a $\$ 1$ w zw. z art. 119a $\$ 5$ O.p.

${ }^{26}$ Stanowisko takie prezentuje m.in. Hanna Filipczyk. Zob. H. Filipczyk, Status etyczny unikania opodatkowania i jego znaczenie prawne, „Przegląd Podatkowy” 2017, nr 8, s. 25.

${ }^{27} \mathrm{~K}$. Radzikowski klasyfikuje takie zachowania jako „pośrednie łamanie prawa podatkowego" (K. Radzikowski, Planowanie podatkowe a obejście prawa, [w:] Ł. Ziółek (red.) (praca zbiorowa), Międzynarodowe planowanie podatkowe, Warszawa 2007, s. 195-196), a A. Zalasiński jako „pozornie legalne” unikanie opodatkowania (A. Zalasiński, Nadużycie swobody przedsiębiorczości a unikanie opodatkowania - glosa do wyroku ETS z 12.09.2006 r. w sprawie C-196/04 Cadbury Schweppes plc, Cadbury Schweppes Overseas Ltd przeciwko Commissioners of Inland Revenue, „Europejski Przegląd Sądowy" 2007, nr 1, s. 44).

${ }^{28}$ Podobnie M. Kondej, Klauzula przeciwko unikaniu opodatkowania. Komentarz do przepisów materialnoprawnych, Poznań 2018, s. 16-17. 
nia skierowane przeciwko unikaniu opodatkowania, nie oznacza jeszcze, iż zjawisko to staje się naraz „nielegalne”. W przypadku zastosowania wewnątrzkrajowego środka antyabuzywnego, jakim par excellence jest GAAR, unikanie opodatkowania staje się tylko względnie bezskuteczne - skutki czynności prawnej zostają uchylone na gruncie prawa podatkowego, lecz zachowują skuteczność na gruncie prawa cywilnego ${ }^{29}$. Środek ten znajduje zastosowanie wyłącznie w stosunku do podatników, którzy swe działania opierają na przepisach prawa i działają legalnie ${ }^{30}$.

Definiowanie „legalności” unikania opodatkowania jako działań podatników dopuszczalnych na gruncie obowiązujących zasad wykładni prawa podatkowego, bez odniesienia do regulacji kodeksu karno-skarbowego czy rzeczywistego (pozornego) charakteru czynności prawnych na gruncie prawa cywilnego, jest niepoprawne metodologicznie i wprowadza niepotrzebne zamieszanie w istniejącej siatce pojęciowej „form oporu podatkowego". Powoduje to, iż nadal wśród części przedstawicieli aparatu skarbowego zdaje się niestety pokutować przekonanie, że uchylanie się od opodatkowania i unikanie opodatkowania to pojęcia tożsame ${ }^{31}$.

W konsekwencji, właściwsze wydaje się mówienie o warunkach funkcjonowania „legalnego na gruncie systemowym (efektywnego na gruncie podatkowym)” unikania opodatkowania ${ }^{32}$. „Legalność systemowa” unikania opodatkowania powinna być przy tym odnoszona nie tylko do zasad wykładni prawa podatkowego, lecz również należy ją rozpatrywać przez pryzmat obowiązujących w danym systemie podatkowym środków antyabuzywnych ${ }^{33}$.

${ }^{29}$ M. Gordon, Obejście prawa czy unikanie opodatkowania? Uwagi terminologiczne, „Toruński Rocznik Podatkowy” 2013, s. 176-177.

${ }^{30}$ M. Kolibski, K. Turzyński, Reguła intertemporalna klauzuli ogólnej przeciwko unikaniu opodatkowania w świetle standardów konstytucyjnych - polemika, „Przegląd Podatkowy” 2016, nr 12, s. 17-23.

${ }^{31}$ Tezę tę potwierdza próba stosowania przez administrację skarbową art. 199a Ordynacji podatkowej do zwalczania sztucznych struktur podatkowych ważnych na gruncie prawa cywilnego (unikanie opodatkowania), podczas gdy hipoteza niniejszego przepisu dotyczyła czynności pozornych, bezwzględnie nieważnych na gruncie cywilnym i karalnych na gruncie kodeksu karno-skarbowego (zob. W. Nykiel, M. Wilk, Nieprzydatność art. 199a \$ 2 ordynacji podatkowej w walce $z$ unikaniem opodatkowania a nastepstwa czynności pozornych, „Przegląd Podatkowy” 2017, nr 2, s. 20).

32 W wyroku z 11 maja 2004 r. (sygn. akt K 4/03) TK posługiwał się zwrotem „legalność o charakterze systemowym” dla właściwego opisania natury problemu.

${ }^{33}$ Podobnie J. Jankowski, Optymalizacja podatkowa..., s. 118. 
5. ZAKRES OCHRONY PODATNIKÓW UNIKAJĄCYCH OPODATKOWANIA - UWAGI OGÓLNE

Zasada nullum tributum sine lege, wyrażona w art. 84 i 217 Konstytucji, determinuje podstawowe zasady wykładni prawa podatkowego. Zasady te $\mathrm{w}$ polskim systemie prawa podatkowego stanowią niejako ochronę podatnika przed arbitralnością władz podatkowych, a w szczególności mają gwarantować określanie wysokości zobowiązania podatkowego wyłącznie na podstawie jasnych i czytelnych kryteriów znajdujących się w ustawie podatkowej. W przypadku unikania opodatkowania dochodzi do kolizji dwóch wartości konstytucyjnych - zasady ustawowego nakładania podatków oraz zasady równości (art. 31 ust. 1 Konstytucji). Podatnicy cechujący się tożsamą istotną cechą relewantną (zbliżony poziom rentowności z prowadzonej działalności gospodarczej) znajdują się w odmiennej sytuacji prawnopodatkowej, tj. podmiot unikający opodatkowania płaci zobowiązanie podatkowe w znacznie niższej wysokości niż drugi podmiot lub w ogóle go nie płaci ${ }^{34}$. W przypadku wystąpienia unikania opodatkowania prowadzącego do kolizji z art. 32 ust. 1 i art. 84 Konstytucji RP, pierwszeństwo jest przyznawane zasadzie nullum tributum sine lege $e^{35}$. Sytuacja ta częściowo wynika $\mathrm{z}$ orzecznictwa Trybunału Konstytucyjnego, zgodnie z którym postanowienia Konstytucji normujące zasady ogólne nie mogą stanowić samodzielnych wzorców kontroli w zakresie, w jakim określony problem konstytucyjnoprawny doczekał się odrębnej, wyraźnej regulacji w szczegółowych postanowieniach Konstytucji dotyczących poszczególnych wolności i praw obywatelskich ${ }^{36}$. Okoliczność, iż z dobrodziejstw ochronnej funkcji wykładni prawa podatkowego korzystają również podatnicy unikający opodatkowania, nie ma tutaj większego znaczenia. TK w wyroku w sprawie konstytucyjności przepisów o nieujawnionych źródłach przychodu ${ }^{37}$ przyznał wprost, że ukrywanie dochodów (uchylanie się od opodatkowania) oznacza również lekceważenie obowiązku przestrzegania prawa (art. 83 Konstytucji), obowiązku lojalności wobec państwa i troski o dobro wspólne (art. 82 Konstytucji) oraz prowadzi do nieusprawiedliwionego w świetle zasady równości (art. 32 Konstytucji)

${ }^{34}$ Podatnicy skutecznie unikający opodatkowania dzięki korzyściom podatkowym osiągają - bez gospodarczego uzasadnienia - lepsze rezultaty ekonomiczne niż ci podatnicy, którzy nie podejmują tego rodzaju działań. Zob. A. Olesińska, Klauzula ogólna przeciwko unikaniu opodatkowania - moda czy konieczność, „Infos” 2016, nr 5, s. 3-4.

${ }^{35}$ Wyrok NSA z 20 października 2016 r., sygn. akt II FSK 1582/16.

${ }^{36}$ Wyrok TK z 10 marca 2009 r., sygn. akt P 80/08.

${ }^{37}$ Wyrok TK z dnia 18 lipca 2013 r., sygn. akt SK 18/09. 
uprzywilejowania nieuczciwych podatników względem podatników rzetelnie wywiązujących się z powinności podatkowych. Zdaniem TK, argumentacja ta nie jest jednak wystarczająca, aby pozbawić podatników uchylających się od opodatkowania korzystania $\mathrm{z}$ dobrodziejstwa instytucji przedawnienia zobowiązań podatkowych. Wynika to $z$ faktu, iż konstrukcja i terminy przedawnienia w prawie podatkowym muszą zostać określone w sposób jednoznaczny i precyzyjny, a przede wszystkim muszą realizować podstawową funkcję omawianej instytucji, tj. doprowadzenie do ostatecznego wygaśnięcia należności podatkowej, niezależnie od oceny zachowania podatników. Powyższy wyrok TK wskazuje w sposób jednoznaczny, iż zasady wykładni prawa podatkowego nie mogą być „płynne”, w zależności od stanu faktycznego sprawy. Skoro bowiem na ochronę zasługują podatnicy uchylający się od opodatkowania, to tym bardziej na taką ochronę zasługują podatnicy nieunikający opodatkowania. Przyznanie prymatu wykładni celowościowej względem wykładni językowej i dopuszczenie możliwości stosowania analogii stałoby w ewidentnej sprzeczności z zasadą ustawowego nakładania podatków. Wymagałoby znacznego rozszerzenia dotychczasowego pola interpretacji przepisów podatkowych (szerszego zarysowania ram wykładni) - z brzmienia słów ustawy do możliwego sensu słów ustawy ${ }^{38}$. Wówczas jednak spełnione byłyby przesłanki wskazujące na niezachowanie konstytucyjnego standardu należytej określoności przepisów podatkowych, tj.:

- interpretacja przepisu prawnego wypełniona jest elementami subiektywnymi;

- treść przepisu prawnego nie jest przedmiotem jednolitej linii orzeczniczej;

- ustalenie hipotezy normy prawnej wynikającej z danego przepisu jest rezultatem niedozwolonego prawotwórstwa administracji skarbowej39.

Do 14 lipca 2016 r., wobec braku GAAR, w polskim systemie podatkowym możliwości korzystania z "efektywnego podatkowo” unikania opodatkowania były bardzo szerokie. Obowiązujące zasady wykładni prawa podatkowego umożliwiały podatnikom tworzenie coraz to nowych struktur podatkowych, które w drodze wykładni prawa podatkowego były akceptowane przez sądy administracyjne. Orzecznictwo sądów administracyjnych, stosując "klasyczne” zasady wykładni prawa podatkowego, pozwalało na tworzenie struktur podatkowych pozwalających na osiągnięcie nieuzasadnionych korzyści podatkowych postulowanych przez samych

\footnotetext{
${ }^{38}$ R. Mastalski, op. cit., s. 94.

${ }^{39}$ Zobacz wyrok TK z dnia 11 maja 2004 r., sygn. akt K 4/03.
} 
podatników. Tytułem przykładu można wskazać następujące struktury podatkowe funkcjonujące $\mathrm{w}$ dużym stopniu dzięki orzecznictwu sądów administracyjnych:

- nieopodatkowane wydanie majątku likwidowanej spółki osobowej (powstałej z przekształcenia spółki komandytowo-akcyjnej);

- urealnienie wartości podatkowej aktywów rzeczowych wypłacanych $\mathrm{w}$ formie dywidendy niepieniężnej;

- podwyższenie kosztu uzyskania podatkowego sprzedawanego aktywa rzeczowego poprzez wcześniejsze wniesienie w formie aportu do spółki osobowej $^{40}$.

Powstaje zatem pytanie, czy wobec ewentualnego braku GAAR, względnie innych podobnych środków antyabuzywnych w polskim systemie podatkowym, podatnicy unikający opodatkowania mogą w sposób zupełnie „nieskrępowany” tworzyć efektywne podatkowo sztuczne struktury korporacyjne i czerpać $\mathrm{z}$ nich nieuzasadnione korzyści podatkowe? W doktrynie prawa podatkowego można spotkać się z postulatami obniżenia standardów ochrony dla podatników unikających opodatkowania ${ }^{41}$. Mając na uwadze orzecznictwo Trybunału Konstytucyjnego i brak realnej możliwości zmiany treści aktualnie obowiązującej Konstytucji - zdaniem autora tego tekstu - zasadne jest rozważenie następujących postulatów:

- odważniejsze sięgnięcie do tzw. głębokiej struktury podatku CIT i podjęcie próby wykształcenia na drodze orzeczniczej zasad systemowych (konstrukcyjnych) CIT - postulat de lege lata;

- zmiana wykładni art. 84 Konstytucji poprzez wywiedzenie z treści tego przepisu zasady powszechności opodatkowania - postulat de lege lata;

- ograniczenia w sferze instytucjonalno-proceduralnej dla podatników unikających opodatkowania - postulat de lege ferenda.

${ }^{40}$ Więcej na temat korzyści podatkowych związanych ze stosowaniem tych struktur oraz przyjętych przez sądy administracyjne zasad wykładni w: H. Filipczyk, Sądy administracyjne jako promotor unikania opodatkowania $w$ podatkach dochodowych, https://www.academia.edu/28814677/S\%C4\%84DY_ADMINISTRACYJNE_JAKO_ PROMOTOR_UNIKANIA_OPODATKOWANIA_W_PODATKACH_DOCHODOWYCH [dostęp 7.08.2018].

${ }^{41}$ Postuluje się obniżenie poziomu ochrony podatników unikających opodatkowania, ponieważ aktualne standardy ochrony sformułowane są na tak wysokim poziomie, iż stworzenie odpowiednich wewnątrzkrajowych środków antyabuzywnych spełniających te standardy jest w praktyce niewykonalne (por. D. Mączyński, Wpływ orzecznictwa Trybunału Konstytucyjnego na trwałość instytucji materialnego prawa podatkowego, „Ruch Prawniczy, Ekonomiczny i Socjologiczny" 2014, z. 3, s. 27). 
6. SiĘGNIĘCIE DO TZW. GŁĘBOKIEJ STRUKTURY PODATKU CIT I WYKSZTAŁCENIE NA DRODZE ORZECZNICZEJ ZASAD SYSTEMOWYCH (KONSTRUKCYJNYCH) PODATKU CIT

Głęboka struktura podatku to założenia konstrukcyjne niemające postaci przepisu, ale które można zrekonstruować (odtworzyć) w drodze całościowej analizy aktu prawnego ${ }^{42}$. Wykształcenie przez judykaturę zasad kształtujących strukturę wewnętrzną podatku CIT niewątpliwie w dużym stopniu zmniejszyłoby ułomność tworzonego prawa podatkowego, jak również pozwoliłoby w dokładniejszy sposób wyznaczyć prawne granice unikania opodatkowania. Analogicznie zasady funkcjonują już od blisko dekady na gruncie podatku VAT (np. zasada neutralności). Recepcja powyższych zasad do kanonów wykładni przepisów ustaw o podatkach dochodowych na drodze orzeczniczej nie byłaby zatem niczym szczególnym. Poniżej zostaną zaprezentowane przykładowe schematy unikania opodatkowania, które ostatecznie nie stały się „efektywne podatkowo” na skutek orzecznictwa sądów administracyjnych wykorzystujących zasady systemowe CIT. Przykłady te mają wskazywać na zasadność i celowość dalszego kształtowania zasad systemowych CIT na drodze orzeczniczej.

\subsection{Darowizny w ramach podatkowej grupy kapitałowej - stan prawny do 31.12.2017 r. (przykład 1)}

Spółki kapitałowe A i B tworzą podatkową grupę kapitałową (PGK). Spółka A dokonuje darowizny znaku towarowego na rzecz Spółki B. Powstaje pytanie, w jakiej wysokości Spółka A powinna rozpoznać koszt podatkowy:

- wartości rynkowej z dnia dokonania darowizny pomiędzy A i B (wariant 1),

- rzeczywiście poniesionych wydatków przez A (wariant 2$)^{43}$.

W przypadku przyjęcia wariantu 1 jako prawidłowego powstaje możliwość nieopodatkowanego ujawnienia wartości znaku towarowego (przeszacowanie do poziomu aktualnej wartości rynkowej). Przychód Spółki B z tytułu darowizny znaku towarowego zostaje rozliczony z kosztem podatkowym Spółki A na poziomie PGK. W ten sposób przychód Spółki B

${ }^{42}$ B. Brzeziński, Wykładnia prawa..., s. 101.

${ }^{43}$ Szerzej na ten temat w: M. Lachowicz, K. Marchocka, Koszty uzyskania przychodów u darczyńcy $w$ przypadku darowizny $w$ formie niepieniężnej $w$ ramach podatkowej grupy kapitałowej, „Przegląd Podatkowy” 2014, nr 9, s. 41-49. 
zostaje skompensowany z kosztem Spółki A, natomiast Spółki B jest uprawniony do amortyzacji darowanego znaku towarowego według jego aktualnej wartości rynkowej ${ }^{44}$.

Rozstrzygając sprawę o zbliżonym stanie faktycznym, NSA opowiedział się za wariantem 1, uznając, że cechy konstrukcyjne CIT wykluczają możliwość dwukrotnego zaliczania tego samego wydatku do kosztów podatkowych przez jeden podmiot (tutaj: PGK), podobnie zresztą jak ta sama wartość nie może być dwukrotnie opodatkowana w odniesieniu do jednego podmiotu ${ }^{45}$. NSA potwierdził wprawdzie, że zasada ta nie jest wprost wyrażona w żadnym z przepisów u.p.d.o.p., jednakże zestawienie obowiązujących regulacji dotyczących sposobu konstruowania podstawy opodatkowania uzasadnia przyjęcie takiego założenia ${ }^{46}$. W opinii sądu, przyjęcie wariantu 1 prowadziłoby do tzw. „karuzeli kosztów” poprzez wielokrotne zaliczanie tego samego wydatku do kosztów podatkowych ${ }^{47}$.

\subsection{Sprzedaż środka trwałego wniesionego aportem do spółki kapitałowej - stan prawny do 31.12.2016 r. (przykład 2)}

Spółka kapitałowa A wnosi wkład niepieniężny w postaci nieruchomości do Spółki kapitałowej B. Wartość aportu zostaje odniesiona w większości na kapitał zapasowy B. Spółka B sprzedaje nieruchomość otrzymaną aportem podmiotowi trzeciemu. Spółka B ma wątpliwość, w jakiej wysokości rozpoznać koszt podatkowy w związku ze sprzedażą nieruchomości:

- wartości początkowej wynikającej z ewidencji środków trwałych Spółki B (wariant 1);

- wartości nominalnej udziałów wydanych Spółce A w zamian za wniesiony aport (wariant 2).

Spółka A w związku z aportem rozpoznaje przychód jedynie z tytułu wartości aportu przekazanej na kapitał zakładowy Spółki B (wartość

${ }^{44}$ Nie jest to przy tym jedyna możliwość nieuzasadnionej redukcji ciężarów fiskalnych z wykorzystaniem darowizn w ramach PGK, możliwa była również redukcja dochodu podatkowego powstałego na transakcji zbycia składnika aktywów (zob.: M. Potyrała, Modyfikacja przepisów regulujacych funkcjonowanie podatkowych grup kapitałowych, „Przegląd Podatkowy” 2018, nr 5, s. 30-31).

${ }^{45} \mathrm{O}$ zasadach systemowych CIT związanych z funkcjonowaniem PGK - zob.: J. Jankowski, Podatkowa grupa kapitałowe daje tylko pozorne korzyści, „Prawo i Podatki” 2014, nr 5, s. 20.

${ }^{46}$ Zob. wyrok NSA z 27 października 2015 r., sygn. akt II FSK 2112/13.

${ }^{47}$ Ibidem. 
nominalna udziałów), natomiast Spółka B ustala wartość początkową nieruchomości w wysokości wartości rynkowej z dnia dokonania aportu. W konsekwencji, na etapie aportu doszło do praktycznie nieopodatkowanego przyrostu wartości majątku w ramach grupy podmiotów powiązanych (Spółki A i B). W przypadku uznania poprawności wariantu 2, Spółka B uzyska ekonomicznie dodatni wynik na transakcji sprzedaży aktywa, jednakże dla celów CIT cała transakcja będzie neutralna podatkowo ze względu na podwyższenie kosztu podatkowego na wcześniejszym etapie transakcji ${ }^{48}$.

NSA, powołując się na zasadę uznawania za koszt podatkowy tylko rzeczywiście poniesionych wydatków, opowiedział się za wariantem $1^{49}$. Zdaniem NSA, wartości początkowej środka trwałego wynikającego z umowy aportowej nie można utożsamiać $\mathrm{z}$ wydatkiem na nabycie środka trwałego. Wartość ta stanowi bowiem wyłącznie efekt wyceny składników majątku wnoszonych do Spółki - nie jest to poniesienie wydatku w rozumieniu przepisów u.p.d.o.p. Kosztem podatkowym może być wyłącznie kwotowo określone zmniejszenie aktywów albo zwiększenie zobowiązań lub rezerw, które prowadzi do zmniejszenia zysków (dochodów), a szerzej kapitałów własnych podatnika, albo do zwiększenia jego strat ${ }^{50}$. W konsekwencji, w przedmiotowej sprawie kosztem podatkowym powinna być wartość nominalna udziałów wydanych w zamian za aport.

6.3. Aport znaku towarowego do Spółki kapitałowej i przekształcenie jej w spółkę osobową - stan prawny do 31.12.2016 r. (przykład 3)

Spółka kapitałowa A wnosi wkład niepieniężny w postaci znaku towarowego do Spółki kapitałowej B. Wartość aportu zostaje odniesiona w większości na kapitał zapasowy B. Spółka B zostaje przekształcona w spółkę osobową. Powstaje wątpliwość, czy Spółka A jako wspólnik Spółki B może zaliczać do kosztów podatkowych odpisy amortyzacyjne od całej wartości początkowej wartości niematerialnej i prawnej (wariant 1) czy też jedynie od wartości przekazanej pierwotnie na kapitał zakładowy Spółki B (wariant 2). Podobnie jak w przykładzie 2, Spółka A w związku z aportem rozpoznaje przychód jedynie z tytułu wartości aportu przekazanej na kapitał

${ }^{48}$ Więcej na ten temat w: J. Jankowski, Aport z agio jako sposób na optymalizację podatkowa, „Nieruchomości” 2014, nr 9, s. 31 i n.

${ }^{49}$ Wyrok NSA z 14 stycznia 2014 r., sygn. akt II FSK 219/12.

${ }^{50}$ Ibidem. 
zakładowy Spółki B (wartość nominalna udziałów), natomiast Spółka B ustala wartość początkową znaku towarowego w wysokości wartości rynkowej z dnia dokonania aportu. Przepisy u.p.d.o.p. w przypadku spółek kapitałowych dopuszczają możliwość zaliczania do kosztów podatkowych odpisów amortyzacyjnych od wartości aportu przekazanej na kapitał zakładowy Spółki kapitałowej (wartość ta stanowi przychód wnoszącego aport). Przepisy u.p.d.o.p nie zawierają jednak regulacji w przypadku, gdy taka spółka kapitałowa zostanie przekształcona w spółkę osobową ${ }^{51}$.

Analizując systematykę przepisów u.p.d.o.p dotyczących amortyzacji środków trwałych i wartości niematerialnych, WSA w Łodzi uznał prawidłowość wariantu 2 ze względu na zasadę kontynuacji amortyzacji u podmiotów łączonych, przekształcanych bądź przejmowanych oraz zakazu amortyzacji środków trwałych nabytych nieodpłatnie w zakresie, w jakim nieodpłatne nabycie nie podlegało opodatkowaniu ${ }^{52}$.

\section{SPRZECZNOŚĆ Z PRZEDMIOTEM I CELEM PRZEPISU USTAWY PODATKOWEJ W ROZUMIENIU PRZEPISÓW ORDYNACJI PODATKOWEJ A ZASADY SYSTEMOWE (CECHY KONSTRUKCYJNE) CIT}

Sprzeczność z przedmiotem i celem przepisu ustawy podatkowej jest jednym z elementów ustawowej definicji unikania opodatkowania, której to wystąpienie uprawnia organ podatkowy do zastosowania klauzuli ogólnej obejścia prawa podatkowego ${ }^{53}$. Ustawodawca w żadnym miejscu nie wyjaśnia jednak, jak należałoby rozumieć sprzeczność z przedmiotem i celem przepisu ustawy podatkowej ${ }^{54}$. Z pewnością pod pojęciem tym nie należy rozumieć zasady powszechności opodatkowania, skutkującego koniecznością nałożenia jak najwyższego podatku w danych okolicznościach. Należy raczej uznać, że ustawodawcy chodziło o działania, które w świetle

${ }^{51}$ Szerzej ma temat tej metody unikania opodatkowania w: P. Dudek, Luka w prawie pozwala na optymalizacje przy przekształceniu, „Dziennik Gazeta Prawna” 2016, 22.03.

52 Zobacz wyrok WSA w Łodzi z 8 grudnia 2016 r., sygn. akt I SA/Łd 846/16, orzeczenie prawomocne.

${ }^{53}$ Stosownie do art. 119a $\$ 1$ O.p., czynność dokonana przede wszystkim w celu osiągnięcia korzyści podatkowej, sprzecznej w danych okolicznościach z przedmiotem i celem przepisu ustawy podatkowej, nie skutkuje osiągnięciem korzyści podatkowej, jeżeli sposób działania był sztuczny.

${ }^{54}$ Zob.: uzasadnienie do rządowego projektu ustawy o zmianie ustawy - Ordynacja podatkowa oraz niektórych innych ustaw, Druk Sejmowy nr 367, Sejm VIII Kadencji, s. 23, http://www.sejm.gov.pl/sejm8.nsf/druk.xsp?nr=367 [dostęp 31.07.2018]. 
określonej normy prawa podatkowego mieszczą się w zakresie jej stosowania, ale równocześnie są niezgodne $\mathrm{z}$ jej duchem ${ }^{55}$. Za prawidłowością tego poglądu przemawia uzasadnienie do projektu ustawy wprowadzającej GAAR, gdzie projektodawca posługuje się zwrotem „działania stojące w sprzeczności z celem i istotą regulacji podatkowych" ${ }^{\text {". }}$. W konsekwencji pod pojęciem sprzeczności z przedmiotem i celem przepisu ustawy podatkowej należałoby rozumieć takie działania podatnika, które są sprzeczne z zasadami systemowymi (konstrukcyjnymi) CIT zdekodowanymi z treści przepisów u.p.d.o.p. powiązanych ze sobą funkcjonalnie (np. regulacje dotyczące amortyzacji czy zasad zaliczania wydatków do kosztów podatkowych). Pogląd ten zdaje się podzielać również szef KAS, o czym świadczy analiza pojęcia „sprzeczności z przedmiotem i celem przepisu ustawy podatkowej" zawarta w jednej z odmów wydania opinii zabezpieczającej ${ }^{57}$. Sprawa dotyczyła nieopodatkowanej wypłaty niepodzielnych zysków zgromadzonych w spółce kapitałowej. Podatnik planował „przenieść” niepodzielne zyski Spółki A do Spółki B w ramach podziału przez wydzielenie i następnie przekształcenie Spółki kapitałowej B w spółkę osobową. Szef KAS przeanalizował przepisy u.p.d.o.p. dotyczące opodatkowania udziałowców/akcjonariuszy w związku z transferem dochodu wypracowanego w spółce kapitałowej, tj:

- wypłata dywidendy;

- przekazanie całości lub części utworzonego kapitału zapasowego na kapitał zakładowy (zwiększenie wartości nominalnej udziałów);

- przekształcenie przedsiębiorstwa w spółkę osobową oraz jego likwidacja, wskutek której następuje przekazanie udziałowcom majątku likwidowanego podmiotu;

- likwidację spółki kapitałowej.

Zdaniem szefa KAS, przepisy u.p.d.o.p. wprowadzają ogólną zasadę opodatkowania dystrybucji zysków spółki kapitałowej do jej wspólników niezależnie od wybranej formy, ponieważ każda z ww. transakcji jest zdarzeniem podlegającym opodatkowaniu na gruncie CIT. W konsekwencji, sposób działania zaprezentowany przez podatnika powinien zostać uznany

${ }^{55}$ M. Kondej, Hipoteza normy klauzuli ogólnej przeciwko unikaniu opodatkowania, „Praktyka Podatkowa” 2016, nr 1, s. 5-6.

${ }_{56}$ Tak też M. Guzek, M. Stefaniuk, Klauzula przeciwko unikaniu opodatkowania, „Monitor Podatkowy” 2016, nr 11, s. 23.

${ }^{57}$ Zob.: odmowa szefa KAS wydania opinii zabezpieczającej z 22 maja 2017 r., nr SP3.8011.4.2016. 
za sprzeczny z przedmiotem i celem przepisu ustawy podatkowej ze względu na niezgodność ze wspomnianą wyżej regułą.

Wprowadzenie sprzeczności z przedmiotem i celem przepisu ustawy podatkowej jako elementu ustawowej definicji unikania opodatkowania powinno wymusić pogłębioną refleksję w doktrynie i judykaturze na temat zasad konstrukcyjnych CIT ${ }^{58}$. Tworzenie zasad systemowych CIT byłoby zjawiskiem akceptowalnym z perspektywy konstytucyjnej, znajdującym odzwierciedlenie w orzecznictwie $\mathrm{TK}^{59}$. Niestety, dotychczasowa praktyka stosowania GAAR niekoniecznie gwarantuje, iż interpretacja terminu sprzeczności z przedmiotem i celem przepisu ustawy podatkowej rzeczywiście przyczyni się do wykształcenia zasad systemowych (cech konstrukcyjnych) CIT. Przykładowo, szef KAS w jednej z odmów wydania opinii zabezpieczającej uznał, iż opodatkowanie według stawki 19\% dochodów kadry zarządzającej osiągniętych w związku $\mathrm{z}$ realizacją programu motywacyjnego opartego na pochodnych instrumentach finansowych jest sprzeczne $z$ przedmiotem i celem przepisów ustawy o podatku dochodowym od osób fizycznych ${ }^{60}$. O ile rzeczywiście sposób działania podatnika przedstawiony w opisanym wniosku można uznać za sztuczny, to już wyprowadzenie z aktualnie obowiązujących regulacji ustawy o podatku dochodowym od osób fizycznych zasady progresywnego opodatkowania dochodów kadry menedżerskiej (według skali podatkowej 18\% i 32\%) należy uznać za zbyt daleko idącą uznaniowość w tworzeniu generalnej zasady systemowej (cechy konstrukcyjnej) podatku.

\section{ZASADA IN DUBIO PRO TRIBUTARIO A GAAR} - POZORNY BRAK KONFLIKTU?

Z dniem 1 stycznia 2016 r. zasada in dubio pro tributario została wprowadzona do Ordynacji podatkowej ${ }^{61}$. Nowo dodany art. 2a stanowi, iż niedające się usunąć wątpliwości co do treści przepisów prawa podatkowego

${ }^{58}$ H. Filipczyk, Status etyczny..., s. 26.

${ }^{59}$ Przykładowo, w wyroku z 22 maja 2002 r., sygn. K 6/02, TK kilkakrotnie podkreślił, że podwójne opodatkowanie jest „sprzeczne z rozwiązaniami prawnymi zawartymi w samej ustawie [o] podatku dochodowym". Innymi słowy, zakaz podwójnego opodatkowania jest zasadą o randze ustawowej, wyprowadzaną z ustaw podatkowych, a niemającą bezpośredniego osadzenia w ustawie zasadniczej.

${ }^{60}$ Zob.: odmowa szefa KAS wydania opinii zabezpieczającej z 19 grudnia 2017 r., nr DOK4.8011.4.2017.

${ }^{61}$ Ustawa z 5 sierpnia 2015 r. o zmianie ustawy - Ordynacja podatkowa oraz niektórych innych ustaw (Dz.U. z 2015 r., poz. 1197). 
rozstrzyga się na korzyść podatnika. Z interpretacji ogólnej Ministra Finansów wynika, że zasada rozstrzygania wątpliwości na korzyść podatnika, wyrażona explicite w przepisach Ordynacji podatkowej, dotyczy tylko wątpliwości co do treści przepisów prawa, a nie wątpliwości co do stanu faktycznego ${ }^{62}$. Przyjmuje się, że stosowanie GAAR w wersji normatywnej jest związane tak naprawdę $\mathrm{z}$ oceną danego stanu faktycznego ad casum i nie ma w zasadzie nic wspólnego z wykładnią przepisów prawa podatkowego. Klauzula ma bowiem charakter fikcji prawnej - w wyniku jej zastosowania zostaje wykreowany modelu sposobu postępowania rozsądnego podatnika kierującego się celami gospodarczymi - innymi niż podatkowe (odpowiedni stan faktyczny w ocenie administracji skarbowej) ${ }^{63}$. Na tej podstawie można wnioskować, że zasada in dubio pro tributario nie znajduje się w potencjalnym konflikcie z GAAR. Przekonanie to jednak jest złudne, zwłaszcza w kontekście silnych związków prawa podatkowego z prawem cywilnym. Określenie wystąpienia podatkowoprawnego stanu faktycznego nie jest zazwyczaj możliwe bez uprzedniej analizy skutków czynności prawnej na gruncie prawa cywilnego ${ }^{64}$. Opisane związki prawa podatkowego z cywilnym sprawiają, iż niektórzy autorzy określają je „prawem podwójnej wykładni" ${ }^{65}$. Jest to trafne sformułowanie, które dobitnie wskazuje, że dokonując reklasyfikacji podatkowej czynności prawnych wskutek stosowania GAAR, organ podatkowy tak naprawdę dokonuje również wykładni przepisów. Dokonywana jest wówczas analiza przepisów z zakresu prawa cywilnego i prawa podatkowego. Przedmiotem wykładni są wtedy zwłaszcza normy prawa podatkowego, które pozwalają ustalić, czy działanie podatnika było sprzeczne z przedmiotem i celem przepisu ustawy podatkowej. Trudno uznać, iż wówczas podatnikowi nie przysługuje prawo do powołania się na zasadę in dubio pro tributario, zwłaszcza gdy istnienie jakiejś zasady systemowej (cechy konstrukcyjnej) CIT jest wysoce wątpliwe.

Dowolności aparatu skarbowego w tworzeniu nieistniejących zasad systemowych CIT na potrzeby stosowania GAAR sprzeciwia się zatem zasada in dubio pro tributario. Wykształcenie cech konstrukcyjnych CIT

${ }^{62}$ Interpretacja ogólna Ministra Finansów z dnia 29 grudnia 2015 r. w sprawie stosowania art. 2a ustawy z dnia 29 sierpnia 1997 r. - Ordynacja podatkowa, nr PK4.8022.44.2015.

${ }^{63} \mathrm{H}$. Filipczyk, Stosowanie klauzuli ogólnej przeciwko unikaniu opodatkowania - zagadnienia wybrane, „Monitor Podatkowy” 2016, nr 7, s. 14.

${ }^{64}$ R. Mastalski, op. cit., s. 27.

${ }^{65}$ B. Brzeziński, Wstęp do nauki prawa podatkowego, Toruń 2003, s. 151. 
powodowałoby, iż niepewność związana ze stosowaniem GAAR dotyczyłaby wyłącznie tych podatników, którzy kształtując swoje stosunki cywilnoprawne w sposób dalece nietypowy, osiągają w ten sposób szczególnie korzystne wyniki wykładni, sprzeczne z zasadami systemowymi CIT ${ }^{66}$. Jeżeli podatnik dokonuje zwykłych czynności cywilnoprawnych do osiągnięcia zamierzonego rezultatu gospodarczego, pozostaje w granicach prawnopodatkowego stanu faktycznego, wyznaczanego przez ścisłe normy prawa podatkowego ${ }^{67}$.

Odesłanie wyłącznie do kryterium „sprzeczności z przedmiotem i celem przepisu ustawy podatkowej" może powodować, iż z ochrony byliby wyłączeni podatnicy uzyskujący „nadsystemowe” korzyści podatkowe, którzy jednak prowadzą realną działalność gospodarczo-inwestycyjną, niemającą charakteru sztucznych struktur podatkowych ${ }^{68}$. Sedno problemu tkwi w tym, czy ustawodawcy „na ołtarzu” walki z unikaniem opodatkowania wolno poświęcić podatników stosujących inne formy oporu podatkowego niż unikanie opodatkowania? Odpowiedź na tak postawione pytanie musi być negatywna. Wyłączenie podatników unikających opodatkowania z zakresu stosowania zasady in dubio pro tributario, bez jednoczesnego precyzyjnego i jasnego zdefiniowania unikania opodatkowania na poziomie ustawowym, należy uznać za niedopuszczalne. Zwłaszcza w kontekście znikomej praktyki stosowania GAAR i związanych z tym wątpliwości co do znaczenia zakresu znaczeniowego sprzeczności z przedmiotem i celem przepisu ustawy podatkowej oraz braku precyzyjnych kryteriów odróżniających unikanie opodatkowania od innych istniejących form oporu podatkowego.

${ }^{66}$ Niektórzy praktycy prawa podatkowego postulują pomijanie rezultatów wykładni szczególnie korzystnych dla podatników w przypadku, gdy analogiczne zdarzenia na gruncie podatku dochodowego nie pozwalałyby na osiągnięcie podobnych korzyści (por.: A. Ossowski, Przekształcenie spółki nie wpływa na koszt nabycia udziałów, „Rzeczpospolita" 2017, 6.03 .

${ }^{67}$ P. Karwat, Obejście prawa podatkowego, „Przegląd Podatkowy” 2003, nr 2, s. 50-51.

${ }^{68}$ Dobrą ilustrację tego problemu stanowi zamieszanie interpretacyjne wokół terminu „część odsetkowa raty leasingowej” na gruncie art. 15c ust. 12 u.p.d.o.p. w brzmieniu obowiązującym od 1 stycznia 2018 r. (zob.: J. Jankowski, Analiza wątpliwości interpretacyjnych wokół terminu „część odsetkowa raty leasingowej” a zasada in dubio pro tributario, „Monitor Podatkowy” 2018, nr 11, s. 26-27). 
9. WykŁadnia ART. 84 Konstytucji w ŚWietle Zasady POWSZECHNOŚCI OPODATKOWANIA

Można spotkać się z poglądem, iż redakcja art. 84 Konstytucji świadczy wyłącznie o istnieniu zasady ustawowego nakładania podatków z pominięciem zasady powszechności opodatkowania. Termin „każdy” nie jest bowiem synonimem słowa „wszyscy” i należy go rozumieć w kontekście, w jakim został zastosowany, czyli „tylko ten, kto" ${ }^{69}$. Adresatem normy nie jest więc „każdy”, lecz „ten, kto” został uznany za podatnika na podstawie przepisów ustaw podatkowych, poddawanych ogólnym zasadom wykładni prawa podatkowego. W konsekwencji, tylko ten, kto jest objęty określonym w ustawie obowiązkiem podatkowym, zobowiązany jest do ponoszenia świadczenia podatkowego ${ }^{70}$. Obowiązek poniesienia ciężarów publicznych ciąży na podatniku jedynie $\mathrm{w}$ takim zakresie, $\mathrm{w}$ jakim wynika to $\mathrm{z}$ ustawy podatkowej ${ }^{71}$.

Według alternatywnej koncepcji, treści przepisu ar. 84 Konstytucji nie należy utożsamiać wyłącznie $\mathrm{z}$ wymogiem ustawowego uregulowania obciążeń podatkowych i przyjmować, że ustanawia on jedynie wyjątek od zasady wolności od ingerencji w prawo własności ${ }^{72}$. Przepis ten stanowi bowiem potwierdzenie obowiązywania zasad powszechności i ustawowego nakładania podatków, spośród których zasada nullum tributum sine lege ma znaczenie istotniejsze ${ }^{73}$.

Niezależnie od trafności ww. koncepcji, każda z nich zakłada „swoisty” prymat zasady ustawowego nakładania podatków ze względu na położenie akcentu na zwrocie „określone w ustawie”. Podobnie orzecznictwo TK potwierdza wprawdzie istnienie zasady powszechności opodatkowania i wskazuje art. 84 Konstytucji jako podstawę funkcjonowania tej zasady, jednakże sposób interpretacji tej zasady pozbawia ją w praktyce większego znaczenia na etapie wykładni przepisów ustaw podatkowych (stosowania prawa podatkowego). Kluczowe elementy zasady powszechności opodatkowania według tez orzeczniczych Trybunału Konstytucyjnego są następujące:

${ }^{69}$ B. Brzeziński, Wstęp do nauki..., s. 141.

${ }^{70}$ Ibidem.

${ }^{71}$ M. Kalinowski, op. cit., s. 57.

${ }^{72}$ R. Mastalski, op. cit., s. 19.

${ }^{73}$ A. Huchla, Ciężary i świadczenia publiczne a podatki $w$ świetle art. 84 Konstytucji Rzeczypospolitej Polskiej, [w:] P. Lewkowicz, J. Stankiewicz (red.), Konstytucyjne uwarunkowania tworzenia i stosowania prawa finansowego i podatkowego, Białystok 2010, s. 147. 
- „każdy” powinien przyczyniać się do zaspokajania wspólnych potrzeb;

- podatkiem są objęte wszystkie stany faktyczne i prawne (przedmiot podatku), określone zjawiska (majątek, obrót, dochód), z którymi wiąże się obowiązek podatkowy;

- w prawidłowo skonstruowanym systemie każdy powinien być objęty obowiązkiem podatkowym, jeżeli spełnione są warunki powstania stosunku podatkowego ${ }^{74}$.

Analiza powyższych elementów „składowych” zasady powszechności opodatkowania prowadzi do konkluzji, iż nacisk jest tu położony na aspekt podmiotowy niniejszej zasady („każdy” powinien przyczyniać się do zaspokajania wspólnych potrzeb). $Z$ art. 84 Konstytucji nie należy natomiast wywodzić dyrektywy powszechności opodatkowania w znaczeniu przedmiotowym, a zatem wymogu objęcia podatkiem wszystkich sfer aktywności jednostki (wszystkich możliwych zjawisk ekonomicznych) ${ }^{75}$. Powszechność opodatkowania $\mathrm{w}$ znaczeniu przedmiotowym to $\mathrm{w}$ zasadzie jedynie postulat prowadzenia efektywnej polityki fiskalnej, skierowany do ustawodawcy podatkowego ${ }^{76}$. Położenie akcentu na aspekt podmiotowy zasady powszechności opodatkowania, przy jednoczesnej marginalizacji elementu przedmiotowego, powoduje szereg istotnych konsekwencji:

- prawnopodatkowe stany faktyczne są tworzone przez ustawodawcę na podstawie „technicznych” przepisów ustaw podatkowych i nie istnieją realnie w życiu społecznym (poza tekstem ustawy podatkowej), należy więc uznać, że w prawie podatkowym nie występują luki o charakterze aksjologicznym;

- zasada równości została już uwzględniona przez ustawodawcę przy tworzeniu prawa podatkowego, natomiast przy jego stosowaniu uwzględnia się ją podczas wykładni. Jeżeli zatem wykładnia prawa podatkowego prowadzi do wniosku, że spośród dwóch stanów faktycznych o tożsamej treści gospodarczej ustawodawca chciał opodatkować tylko jeden, to należy przyjąć, że z woli ustawodawcy zasada równości ulega ograniczeniu ${ }^{77}$.

${ }^{74}$ Por. wyrok TK z 28 października 2015 r., sygn. akt K 21/14.

${ }^{75}$ Zob. wyrok TK z 18 listopada 2014 r., sygn. akt K 23/12.

${ }^{76}$ Zob. A. Krzywoń, Podatki i inne daniny publiczne w Konstytucji Rzeczypospolitej Polskiej, Warszawa 2011, s. 81-82.

${ }^{77}$ Krytycznie wobec tej koncepcji P. Karwat (zob.: P. Karwat, op. cit., s. 49). Przykładowo, w Niemczech przepisy podatkowe, które ułatwiają unikanie opodatkowania, są uznawane za niekonstytucyjne ze względu na naruszenie konstytucyjnej zasady równości 
Unikanie opodatkowania pozostanie działaniem cechującym się legalnością o charakterze systemowym na poziomie wykładni prawa podatkowego, dopóki aspekt przedmiotowy zasady powszechności opodatkowania nie będzie rozumiany jako sytuacja, w której wszystkie podmioty znajdujące się w takiej samej sytuacji ekonomicznej (w zakresie stanu majątkowego, rodzajów źródeł przychodów i ich wielkości) są opodatkowane na identycznych zasadach. Oczywiście, postulat ten można wywodzić z zasady równości i sprawiedliwości, jednak tylko w sytuacji, gdy zostanie on umiejscowiony w ramach zasady powszechności opodatkowania, możliwe będzie przyjęcie odmiennych zasad wykładni w przypadku podatników unikających opodatkowania.

10. OGRANICZENIA PROCEDURALNO-INSTYTUCJONALNE DLA PODATNIKÓW UNIKAJĄCYCH OPODATKOWANIA

Choć zasady równości i sprawiedliwości stoją niżej w hierarchii wartości konstytucyjnych niż zasada nullum tributum sine lege i nie mogą być wykorzystywane jako przesłanki do ograniczenia ochrony podatników unikających opodatkowania na poziomie wykładni prawa podatkowego, to jednak mają znaczenie z perspektywy ogólnie postrzeganych funkcji prawa jako „sztuki tego, co dobre i sprawiedliwe”78. Wydaje się, że jest to odróżnienie dwóch zasadniczych kwestii - normatywnej konstrukcji podatku oraz otoczenia prawnego, w jakim on funkcjonuje. Element oceny słusznościowej (zasady równości i sprawiedliwości) na gruncie prawa podatkowego ma dużo większe znaczenie w tym ostatnim przypadku. Przykładowo, pozbawienie podatników uchylających się od opodatkowania dobrodziejstwa instytucji przedawnienia zobowiązania podatkowego nie jest dopuszczalne, natomiast opodatkowanie ukrywanych nielegalnie dochodów według stawki sankcyjnej w wysokości 75\% jest już dopuszczalne ${ }^{79}$. Nie jest możliwe zwalczanie unikania opodatkowania poprzez pozaustawowe rozszerzenie przedmiotu opodatkowania w drodze wykładni rozszerzającej czy zastosowanie analogii. Podobne wnioski płyną z wyroku TK dotyczącego skargi pauliańskiej odnośnie do należności podatkowych ${ }^{80}$. Sytuacje, które

(zob.: H. Litwińczuk, Regulacje o cenach transferowych a ogólna norma przeciwko unikaniu opodatkowania, „Przegląd Podatkowy” 2018, nr 10, s. 21).

${ }^{78}$ Wyrok TK z 10 marca 2009 r., sygn. akt P 80/08.

${ }^{79}$ Wyrok TK z 18 lipca 2013 r., sygn. akt SK 18/09.

${ }^{80}$ Wyrok TK z 18 kwietnia 2018 r., sygn. akt K 52/16. 
nie kreują nowej sytuacji materialno-prawnej w sferze prawa podatkowego, nie podlegają „rygoryzmowi” wykładni prawa podatkowego związanego ze stosowaniem zasady nullum tributum sine lege. Regulacje prawnopodatkowe niewkraczające w obszar uprawnień i obowiązków podatkowych o charakterze materialno-prawnym mogą być w większym stopniu analizowane przez pryzmat zasady równości, sprawiedliwości czy powszechności opodatkowania. Do takich regulacji należałoby również zaliczyć instytucjonalne procesowe gwarancje dla podatników, które mają ich chronić przed arbitralnością administracji skarbowej. Z instytucjonalnej ochrony w tym zakresie korzystają również zazwyczaj podatnicy unikający opodatkowania.

Dobitnym przykładem może być sposób wykorzystania przez podatników instytucji interpretacji przepisów prawa podatkowego do agresywnej optymalizacji podatkowej. Wśród podatników ukształtowała się praktyka dzielenia zapytania o skutki jednej operacji gospodarczej na odrębne elementy (etapy operacji gospodarczej), a dodatkowo pytania w odrębnych wnioskach o różne warianty tej samej operacji ${ }^{81}$. Podatnicy uzyskiwali w ten sposób od administracji skarbowej poradę, w jaki sposób nie płacić podatków w Polsce. Problem wykorzystania urzędowych interpretacji przepisów prawa podatkowego do unikania opodatkowania był dostrzegany przez judykaturę, która wskazywała, iż abstrakcyjny, niejednoznaczny, wielowątkowy, wielowariantowy stan faktyczny nie może być przedmiotem wniosku o wydanie interpretacji indywidualnej ${ }^{82}$. Ostatecznie ustawodawca wraz z wprowadzeniem GAAR zdecydował, iż sytuacje mogące potencjalnie stanowić przypadki unikania opodatkowania nie mogą być przedmiotem wniosku o wydanie interpretacji przepisów prawa podatkowego ${ }^{83}$. Jednocześnie, w przedmiocie instytucji klauzuli obejścia prawa podatkowego i interpretacji przepisów prawa podatkowego wydanych przed jej wejściem w życie powstawało pytanie, czy wydane interpretacje mogą chronić przed

${ }^{81}$ W. Morawski, Urzędowe interpretacje prawa podatkowego - od GAAR do KAS, „Przegląd Podatkowy” 2017, nr 4, s. 33.

${ }^{82}$ Tak m.in. NSA w wyroku z 19 kwietnia 2016 r., sygn. akt II FSK 536/14.

${ }^{83} \mathrm{Na}$ mocy ustawy wprowadzającej GAAR do Ordynacji podatkowej został wprowadzony art. 14b $\$ 5$ b O.p., zgodnie z którym „Nie wydaje się interpretacji indywidualnej w zakresie tych elementów stanu faktycznego lub zdarzenia przyszłego, co do których istnieje uzasadnione przypuszczenie, że mogą być przedmiotem decyzji wydanej z zastosowaniem art. 119a”. 
zastosowaniem GAAR ${ }^{84}$ ? Dochodziło do kolizji wartości, z jednej strony występowała konieczność przeciwdziałania naruszeniu zasady równości poprzez wykorzystanie interpretacji podatkowych do unikania opodatkowania, a z drugiej strony - zmniejszenie zakresu ochrony instytucjonalnej podatników. Ostatecznie NSA uznał, iż interpretacje uzyskane uprzednio, przed wejściem w życie GAAR, nie chronią podatnika przed ewentualnym zastosowaniem klauzuli obejścia prawa podatkowego ${ }^{85}$. Uzasadnieniem dla możliwości zmniejszenia zakresu ochrony instytucjonalnej dla podatników unikających opodatkowania był fakt, że instytucje urzędowych interpretacji podatkowych nie są związane ze stosowaniem przepisów prawa materialnego regulujących określony podatek ${ }^{86}$.

Ustawodawca, zamiast wprowadzać kolejne środki antyabuzywne lub przepisy ukierunkowane na likwidację partykularnych sztucznych struktur podatkowych, powinien rozważyć podjęcie alternatywnych działań na zupełnie nowej płaszczyźnie, jaką są instytucjonalno-procesowe gwarancje chroniące podatników przed arbitralnością administracji skarbowej.

\section{Podsumowanie}

Unikanie opodatkowania może cechować się legalnością o charakterze systemowym (być efektywne podatkowo) na gruncie prawa podatkowego pod warunkiem istnienia określonych reguł wykładni dla tej gałęzi prawa (prymat wykładni językowej, zakaz stosowania analogii na niekorzyść podatników etc.). Istnienie w systemie prawa GAAR w sposób systemowy znacząco ogranicza możliwości efektywnego podatkowo unikania opodatkowania, jednakże nie oznacza to definitywnego rozwiązania problemu funkcjonowania zjawiska unikania opodatkowania w podatkach dochodowych. Dotychczasowa znikoma praktyka stosowania GAAR nie pozwala w sposób jednoznaczny stwierdzić, czy efekt ten nie ma jedynie charakteru tymczasowego. W przypadku gdyby GAAR pozostała „martwym”

${ }^{84}$ Pomijam tutaj świadomie kwestię możliwości stosowania GAAR do odnoszenia korzyści podatkowych wynikających z transakcji dokonanych przed wejściem w życie klauzuli obejścia prawa podatkowego i związanych z tym przepisów intertemporalnych zawartych w ustawie wprowadzającej GAAR (szerzej na ten temat w: M. Kondej, Problematyka intertemporalna stosowania klauzuli przeciwko unikaniu opodatkowania, „Przegląd Podatkowy" 2017, nr 7, s. 20-27).

${ }^{85}$ Zob.: wyrok NSA z 18 grudnia 2017 r., sygn. akt II FSK 2877/17.

${ }^{86}$ Por.: uchwała NSA z dnia 25 czerwca 2012 r., sygn. akt I FPS 4/12. 
narzędziem w rękach administracji skarbowej lub została uznana za niekonstytucyjną przez Trybunał Konstytucyjny wskutek kolizji z zasadą in dubio pro tributario (każdy z tych scenariuszy wydaje się na obecnym etapie wysoce prawdopodobny), podatnicy znów uzyskują praktycznie nieograniczone możliwości unikania opodatkowania. Konstytucyjna zasada nullum tributum sine lege nie pozwala bowiem na zmianę dotychczasowego zakazu wykładni w sposób prowadzący do rozszerzenia przedmiotu opodatkowania na podstawie kryteriów pozaustawowych. Możliwość taka istniałaby w przypadku innego rozumienia w orzecznictwie Trybunału Konstytucyjnego zasady powszechności opodatkowania w znaczeniu przedmiotowym. Pewnym remedium może być „pełniejsze” wykształcenie zasad systemowych (cech konstrukcyjnych) CIT, które w niektórych przypadkach były już wykorzystywane przez sądownictwo administracyjne do odmowy przyznania podatnikom nieuzasadnionych korzyści podatkowych, będących rezultatem nader korzystnej dla nich wykładni. Alternatywnie ustawodawca może podejmować działania zmniejszające zakres ochrony podatników unikających opodatkowania w sferze instytucjonalno-procesowej, która nie jest związana bezpośrednio ze stosowaniem przepisów materialnego prawa podatkowego wyznaczających zakres obowiązku podatkowego.

\section{Bibliografia}

Brzeziński B., Narodziny i upadek orzeczniczej doktryny obejścia prawa podatkowego, „Przegląd Orzecznictwa Podatkowego” 2004, nr 1.

Brzeziński B., Wstęp do nauki prawa podatkowego, Toruń 2003.

Brzeziński B., Wykładnia prawa podatkowego, Gdańsk 2013.

Brzeziński B., R. Korgol, Doktryna substance over form w orzecznictwie podatkowym sqdów w Kanadzie, „Toruński Rocznik Podatkowy” 2011.

Dudek P., Luka w prawie pozwala na optymalizacjęprzy przekształceniu, „Dziennik Gazeta Prawna" 2016, 22.03.

Filipczyk H., Sady administracyjne jako promotor unikania opodatkowania w podatkach dochodowych, https://www.academia.edu

Filipczyk H., Status etyczny unikania opodatkowania i jego znaczenie prawne, „Przegląd Podatkowy" 2017, nr 8.

Filipczyk H., Stosowanie klauzuli ogólnej przeciwko unikaniu opodatkowania - zagadnienia wybrane, „Monitor Podatkowy” 2016, nr 7.

Gordon M., Obejście prawa czy unikanie opodatkowania ? Uwagi terminologiczne, „Toruński Rocznik Podatkowy" 2013. 
Guzek M., Stefaniuk M., Klauzula przeciwko unikaniu opodatkowania, „Monitor Podatkowy" 2016, nr 11.

Huchla A., Ciężary i świadczenia publiczne a podatki w świetle art. 84 Konstytucji Rzeczypospolitej Polskiej, [w:] P. Lewkowicz, J. Stankiewicz (red.), Konstytucyjne uwarunkowania tworzenia $i$ stosowania prawa finansowego i podatkowego. Wyd. Temida 2, Białystok 2010.

Jankowski J., Analiza wątpliwości interpretacyjnych wokół terminu „część odsetkowa raty leasingowej” a zasada in dubio pro tributario, „Monitor Podatkowy” 2018, nr 11.

Jankowski J., Aport z agio jako sposób na optymalizację podatkową, „Nieruchomości” 2014, nr 9.

Jankowski J., Optymalizacja podatkowa w podatkach dochodowych - dopuszczalność oraz prawne granice, Wyd. C.H. Beck, Warszawa 2019.

Jankowski J., Podatkowa grupa kapitałowa daje tylko pozorne korzyści, „Prawo i Podatki” 2014, nr 5.

Kalinowski M., Granice legalności unikania opodatkowania w polskim systemie podatkowym, Towarzystwo Naukowe Organizacji i Kierownictwa, Toruń 2001.

Karwat P., Obejście prawa podatkowego, „Przegląd Podatkowy” 2003, nr 2.

Kociak N., Wykładnia gospodarcza w orzecznictwie sądów administracyjnych, „Przegląd Podatkowy" 2018, nr 4.

Kondej M., Granice optymalizacji podatkowej w podatkach dochodowych przed wejściem $w$ życie klauzuli przeciwko unikaniu opodatkowania, Polskie Wydawnictwo Prawnicze Iuris, Poznań 2017.

Kondej M., Hipoteza normy klauzuli ogólnej przeciwko unikaniu opodatkowania, „Praktyka Podatkowa" 2016, nr 1.

Kondej M., Klauzula przeciwko unikaniu opodatkowania. Komentarz do przepisów materialnoprawnych, Polskie Wydawnictwo Prawnicze Iuris, Poznań 2018.

Kondej M., Problematyka intertemporalna stosowania klauzuli przeciwko unikaniu opodatkowania, „Przegląd Podatkowy” 2017, nr 7.

Kosikowski C., Autonomia prawa podatkowego - głos krytyczny, „Przegląd Podatkowy” 2006, nr 7.

Krzywoń A., Podatki i inne daniny publiczne w Konstytucji Rzeczypospolitej Polskiej, Warszawa 2011.

Lachowicz M., Marchocka K., Koszty uzyskania przychodów u darczyńcy w przypadku darowizny $w$ formie niepieniężnej $w$ ramach podatkowej grupy kapitałowej, „Przegląd Podatkowy" 2014, nr 9.

Litwińczuk H., Regulacje o cenach transferowych a ogólna norma przeciwko unikaniu opodatkowania, „Przegląd Podatkowy” 2018, nr 10.

Mariański A., Rozstrzyganie wątpliwości na korzyść podatnika, cz. II, „Przegląd Podatkowy" 2009, nr 10.

Mastalski R., Stosowanie prawa podatkowego, Wolters Kluwer, Warszawa 2008.

Mączyński D., Wpływ orzecznictwa Trybunału Konstytucyjnego na trwałość instytucji materialnego prawa podatkowego, „Ruch Prawniczy, Ekonomiczny i Socjologiczny” 2014, z. 3 . 
Morawski L., Wstęp do prawoznawstwa, Toruń 1999.

Morawski L., Wykładnia w orzecznictwie sądów, Torun 2002.

Morawski W., Urzędowe interpretacje prawa podatkowego - od GAAR do KAS, „Przegląd Podatkowy" 2017, nr 4.

Nykiel W., Wilk M., Nieprzydatność art. 199a \$ 2 ordynacji podatkowej w walce z unikaniem opodatkowania a następstwa czynności pozornych, „Przegląd Podatkowy” 2017, nr 2.

Olesińska A., Klauzula ogólna przeciwko unikaniu opodatkowania - moda czy konieczność, Biuro Analiz Sejmowych, „Infos” 2016, nr 5.

Ossowski A., Przekształcenie spółki nie wpływa na koszt nabycia udziałów, „Rzeczpospolita" 2017, 6.03.

Potyrała M., Modyfikacja przepisów regulujacych funkcjonowanie podatkowych grup kapitałowych, „Przegląd Podatkowy” 2018, nr 5.

Radzikowski K., Obejście prawa podatkowego w najnowszym orzecznictwie sądów administracyjnych, „Przegląd Podatkowy” 2010, nr 6.

Radzikowski K., Planowanie podatkowe a obejście prawa, [w:] Ł. Ziółek (red.), Międzynarodowe planowanie podatkowe, Difin, Warszawa 2007.

Zalasiński A., Nadużycie swobody przedsiębiorczości a unikanie opodatkowania - glosa do wyroku ETS z 12.09.2006 r. w sprawie C-196/04 Cadbury Schweppes plc, Cadbury Schweppes Overseas Ltd przeciwko Commissioners of Inland Revenue, „Europejski Przegląd Sądowy” 2007, nr 1.

\section{THE SCOPE OF THE PROTECTION OF TAXPAYERS AVOIDING TAX \\ IN THE LIGHT OF THE IN DUBIO PRO TRIBUTARIO PRINCIPLE AND SYSTEMIC PRINCIPLES OF CIT}

Summary. As part of this publication, the key issue of legal protection of taxpayers avoiding taxation are analyzed. This issue is analyzed especially in the context of the in dubio pro tributario principle, construction (systemic) principles of CIT and general anti avoidance rules. The appropriate de lege lata and de lege ferenda postulates aimed at constructing the correlation (interdependence) between these matters at the statutory level are formulated.

Keywords: tax avoidance, principle of in dubio pro tributario, domestic anti-avoidance rules, general anti-avoidance rules, the principle of common taxation. 